\title{
Rapid viral metagenomics using SMART-9N amplification and
}

\section{nanopore sequencing [version 1; peer review: 2 approved with}

\section{reservations]}

Ingra M. Claro (1-3, Mariana S. Ramundo(i)1, Thais M. Coletti(D1, Camila A. M. da Silva (D1), Ian N. Valenca (D1), Darlan S. Candido1,4,

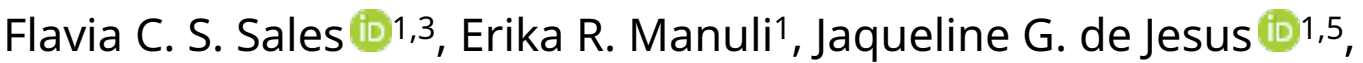
Anderson de Paula1, Alvina Clara Felix¹, Pamela dos Santos Andrade1,6, Mariana C. Pinho ${ }^{1}$, William M. Souza (D)7, Mariene R. Amorim, José Luiz Proenca-Modena,9, Esper G. Kallas³, José Eduardo Levi1,10, Nuno Rodrigues Faria(iD)1,4,5, Ester C. Sabino (iD), Nicholas J. Loman (iD), Joshua Quick²

\footnotetext{
${ }^{1}$ Instituto de Medicina Tropical, Faculdade de Medicina da Universidade de São Paulo, Sao Paulo, 05403-000, Brazil

${ }^{2}$ School of Biosciences, University of Birmingham, Birmingham, B15 2TT, UK

${ }^{3}$ Faculdade de Medicina da Universidade de São Paulo, Sao Paulo, 05403-000, Brazil

${ }^{4}$ Department of Zoology, University of Oxford, Oxford, OX1 3SZ, UK

${ }^{5}$ MRC Centre for Global Infectious Disease Analysis, J-IDEA, Imperial College London, London, SW7 2AZ, UK

${ }^{6}$ Faculdade de Saúde Pública da Universidade de São Paulo, Sao Paulo, 01246-904, Brazil

${ }^{7}$ World Reference Center for Emerging Viruses and Arboviruses and Department of Microbiology and Immunology, University of Texas Medical Branch, Galveston, TX, 77555, USA

${ }^{8}$ Laboratory of Emerging Viruses, Department of Genetics, Microbiology, and Immunology, Institute of Biology, University of Campinas, Campinas, 13083-862, Brazil

${ }^{9}$ Experimental Medicine Research Cluster, University of Campinas, Campinas, 13083-862, Brazil

10DASA, Sao Paulo, 06455-010, Brazil
}

V1 First published: 20 Sep 2021, 6:241

https://doi.org/10.12688/wellcomeopenres.17170.1

Latest published: 24 Apr 2023, 6:241

https://doi.org/10.12688/wellcomeopenres.17170.2

\section{Abstract}

Emerging and re-emerging viruses are a global health concern. Genome sequencing as an approach for monitoring circulating viruses is currently hampered by complex and expensive methods.

Untargeted, metagenomic nanopore sequencing can provide genomic information to identify pathogens, prepare for or even prevent outbreaks.

SMART (Switching Mechanism at the 5' end of RNA Template) is a popular method for RNA-Seq but most current methods rely on oligodT priming to target polyadenylated mRNA molecules. We have developed two random primed SMART-Seq approaches, 'SMART-9N', and a version compatible with barcoded PCR primers available from

\section{Open Peer Review}

Approval Status ? ?

1

2

version 2

(revision)

24 Apr 2023

version 1

20 Sep 2021

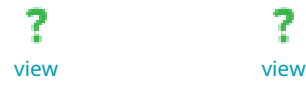

1. Edward Cunningham-Oakes iD, University of Liverpool, Liverpool, UK 
Oxford Nanopore Technologies, 'Rapid SMART-9N', for the detection, characterization, and whole-genome sequencing of RNA viruses. The methods were developed using viral isolates, clinical samples, and compared to a gold-standard amplicon-based method. From a Zika virus isolate the SMART-9N approach recovered $10 \mathrm{~kb}$ of the $10.8 \mathrm{~kb}$ RNA genome in a single nanopore read. We also obtained full genome coverage at a high depth coverage using the Rapid SMART-9N, which takes only 10 minutes and costs up to $45 \%$ less than other methods. We found the limits of detection of these methods to be $6 \mathrm{e} 00$ focus forming units (FFU)/mL with $99.02 \%$ and $87.58 \%$ genome coverage for SMART-9N and Rapid SMART-9N respectively. Yellow fever virus plasma samples and SARS-CoV-2 nasopharyngeal samples previously confirmed by RT-qPCR with a broad range of Ct-values were selected for validation. Both methods produced greater genome coverage when compared to the multiplex PCR approach and we obtained the longest single read of this study ( $18.5 \mathrm{~kb}$ ) with a SARS-CoV- 2 clinical sample, $60 \%$ of the virus genome using the Rapid SMART-9N method. This work demonstrates that SMART-9N and Rapid SMART-9N are sensitive, low input, and long-read compatible alternatives for RNA virus detection and genome sequencing and Rapid SMART-9N improves the cost, time, and complexity of laboratory work.

\section{Keywords}

RNA virus, metagenomic, nanopore sequencing, genomic surveillance, diagnostic, ZIKV, YFV, SARS-CoV-2

\section{Mirela D'arc Ferreira da Costa (ID), Federal \\ University of Rio de Janeiro, Rio de Janeiro, \\ Brazil}

Any reports and responses or comments on the article can be found at the end of the article. 
Corresponding authors: Nicholas J. Loman (n.j.loman@bham.ac.uk), Joshua Quick (j.quick@bham.ac.uk)

Author roles: Claro IM: Conceptualization, Data Curation, Formal Analysis, Investigation, Methodology, Validation, Visualization, Writing - Original Draft Preparation, Writing - Review \& Editing; Ramundo MS: Conceptualization, Data Curation, Formal Analysis, Visualization, Writing - Original Draft Preparation, Writing - Review \& Editing; Coletti TM: Data Curation, Formal Analysis, Investigation, Methodology, Validation, Visualization; da Silva CAM: Data Curation, Formal Analysis, Investigation, Methodology, Validation, Visualization; Valenca IN : Formal Analysis, Investigation, Visualization; Candido DS: Formal Analysis, Investigation, Visualization, Writing - Review \& Editing; Sales FCS: Data Curation, Formal Analysis, Investigation, Methodology, Validation, Visualization; Manuli ER: Investigation, Methodology, Validation, Visualization; de Jesus JG: Investigation, Methodology, Validation, Visualization; de Paula A: Methodology, Validation, Visualization; Felix AC: Methodology, Validation, Visualization; Andrade PdS: Data Curation, Formal Analysis, Investigation, Methodology, Validation, Visualization; Pinho MC: Data Curation, Formal Analysis, Investigation, Methodology, Validation, Visualization; Souza WM: Writing - Original Draft Preparation, Writing - Review \& Editing; Amorim MR: Methodology, Resources, Validation, Visualization; Proenca-Modena JL: Investigation, Methodology, Resources, Writing - Review \& Editing; Kallas EG: Investigation, Methodology, Resources, Validation, Visualization; Levi JE: Investigation, Methodology, Resources, Validation, Visualization; Faria NR: Resources, Supervision, Writing - Original Draft Preparation, Writing - Review \& Editing; Sabino EC: Conceptualization, Funding Acquisition, Investigation, Methodology, Project Administration, Resources, Supervision, Visualization, Writing - Original Draft Preparation, Writing - Review \& Editing; Loman NJ: Conceptualization, Data Curation, Formal Analysis, Funding Acquisition, Investigation, Methodology, Project Administration, Resources, Supervision, Validation, Visualization, Writing - Original Draft Preparation, Writing - Review \& Editing; Quick J: Conceptualization, Data Curation, Formal Analysis, Funding Acquisition, Investigation, Methodology, Project Administration, Resources, Supervision, Validation, Visualization, Writing - Original Draft Preparation, Writing Review \& Editing

Competing interests: No competing interests were disclosed.

Grant information: This work was supported by a Medical Research Council-São Paulo Research Foundation (FAPESP) CADDE partnership award (MRC MR/S0195/1 and FAPESP 18/14389-0) (https://caddecentre.org); FAPESP/Newton Funds (2017/08012-9), and support from FAPESP for I.M.C (2018/17176-8). M.S.R. is supported by the Faculdade de Medicina da Universidade de São Paulo (FMUSP). T.M.C. (2019/07544-2), C.A.M.S. (2019/21301-5), F.C.S.S. (2018/25468-9), J.G.J. (2018/17176-8, 2019/12000-1, 18/14389-0) and E.C.S (2018/14389-0) are supported by FAPESP. P.S.A. is supported by Coordenação de Aperfeiçoamento de Pessoal de Nível Superior (CAPES) (88887.596940/2021-00). W.M.S is supported by FAPESP (2017/13981-0, 2019/24251-9), Conselho Nacional de Desenvolvimento Científico e Tecnológico (CNPq) (408338/2018-0), and the National Institutes of Health (AI120942). D.S.C is supported by the Clarendon Fund and by the Department of Zoology, University of Oxford. M.R.A is supported by CAPES (88887.356527/2019-00). N.R.F. is supported by a Wellcome Trust Royal Society Sir Henry Dale Fellowship (204311). N.J.L. and J.Q. are supported by the Wellcome ARTIC network (206298). The funders had no role in study design, data collection and analysis, decision to publish, or preparation of the manuscript.

Copyright: @ 2021 Claro IM et al. This is an open access article distributed under the terms of the Creative Commons Attribution License, which permits unrestricted use, distribution, and reproduction in any medium, provided the original work is properly cited.

How to cite this article: Claro IM, Ramundo MS, Coletti TM et al. Rapid viral metagenomics using SMART-9N amplification and nanopore sequencing [version 1; peer review: 2 approved with reservations] Wellcome Open Research 2021, 6:241 https://doi.org/10.12688/wellcomeopenres.17170.1

First published: 20 Sep 2021, 6:241 https://doi.org/10.12688/wellcomeopenres.17170.1 


\section{Introduction}

RNA viruses are responsible for causing a broad range of human and veterinary diseases. In recent decades, RNA viruses have been a major cause of emerging and re-emerging infections, including Zika virus (ZIKV), Dengue virus (DENV), Human Immunodeficiency Virus (HIV), Ebola virus (EBOV), yellow fever virus (YFV), and recently, severe acute respiratory syndrome coronavirus 2 (SARS-CoV-2). The resulting epidemics and pandemics have caused high morbidity, mortality, and economic costs ${ }^{1}$.

To date, our ability to manage these outbreaks is hampered by the challenge of making a definitive clinical diagnosis as many of these viruses are often clinically indistinguishable from those caused by co-circulating viruses and some bacterial pathogens ${ }^{2,3}$. Diagnostic tests can be limited by low specificity, in the case of serological tests, or require a priori knowledge of the viruses to be targeted in the case of RT-PCR (reverse transcription-polymerase chain reaction). For these reasons, acute febrile illness often remains undiagnosed, leading to a failure of epidemiological surveillance. Rapid genomic surveillance systems are essential to identify emerging viruses, detect and monitor viral diversity, and be able to prepare for or even prevent new outbreaks ${ }^{4}$.

New applications have been driven by technological advances in sequencing. The first examples of real-time genomic surveillance ${ }^{5,6}$ were conducted using targeted amplicon sequencing on the MinION (Oxford Nanopore Technologies). These studies exploited the portability of nanopore sequencing to achieve a faster turnaround time by sequencing the samples close to where they were collected. While successful for the EBOV epidemic in West Africa, and ZIKV, CHIKV, DENV, and YFV outbreaks in Brazil ${ }^{7-9}$, this approach is best when the outbreak strain is known but is less suited to diverse viral groups or virus discovery.

Viral metagenomics, the process of sequencing the total viral nucleic acid content in a sample (typically cDNA or DNA), allows the genomic characterization of known and novel viruses in an untargeted manner. This technique is particularly useful for diagnostic, clinical laboratories, and public health surveillance $\mathrm{e}^{10-12}$. However, viral metagenomic sequencing directly from clinical samples can result in poor sensitivity especially in samples with a low abundance of viral genomic material relative to host-derived nucleic acid ${ }^{13-15}$. Metagenomic sequencing using nanopore sequencing has already shown promise by Kafetzopoulou et al. (2018) who reported metagenomic sequencing of LASV, DENV, and CHIKV samples $^{16}$, and by Lewandowski et al. (2019) who sequenced the Influenza virus from respiratory samples ${ }^{17}$.

In this study, we describe a high-sensitivity, low input, SMART approach for nanopore metagenomics of RNA viruses from isolated samples or from clinical samples. The SMART approach was originally described in $2001^{18}$, using oligo-dT priming to target polyadenylated mRNA molecules. We adapted this method to use random priming for cDNA synthesis followed by PCR amplification, and Rapid SMART-9N barcoded PCR primers are used in the PCR amplification enabling the addition of barcodes in a single step. SMART-9N recovered a high proportion of viral reads from ZIKV isolate titrated down to $6 \mathrm{e} 00 \mathrm{FFU} / \mathrm{mL}$ of material input including $94.4 \%$ of the genome in a single read. The methods were validated in YFV and SARS-CoV-2 directly from plasma and residual nasopharyngeal samples, respectively. The performance of this assay was compared to a gold-standard multiplex PCR method ${ }^{19}$, demonstrating improvements in sequencing sensitivity, coverage, depth, cost, and complexity of both SMART-9N and Rapid SMART-9N, enabling enhanced pathogen detection for both diagnostic and surveillance application of RNA viruses.

\section{Methods}

\section{Sample collection}

ZIKV isolate strain BeH815744 (GenBank Accession No. KU365780) was propagated into Vero cells (CCL-81; ATTC, Manssas, USA) with minimum essential medium (MEM) for 2 hours at $37^{\circ} \mathrm{C}$ and $5 \% \mathrm{CO}_{2}$. The supernatant was removed, and MEM supplemented with $2 \%$ fetal bovine serum, $1 \%$ penicillin, and streptomycin were added. The cells were incubated for 4 days until $70 \%$ of cytopathic effect. Subsequently, the cell culture supernatant was collected and viral replication was confirmed through real-time quantitative reverse transcription-PCR (RT-qPCR) ${ }^{20}$ and quantified by an FFU assay in Vero cells ${ }^{21}$. This sample was used to assess the performance of all three methods: multiplex PCR, SMART-9N, and Rapid SMART-9N, and the metagenomics approaches, SMART-9N, and Rapid SMART-9N, was tested in different serial ten-fold MEM dilutions up to $1-1,000,000$ to assess the limit of detection (Extended data: Tables $\mathrm{S} 1$ and $\mathrm{S} 2^{22}$ ).

For methodological validation, human clinical samples included:

- 41 plasma samples previously positive for YFV by RT-qPCR ${ }^{23}$ collected between January 11 and May 10, 2018, with a cut-off value of Ct-values $\leq 37$ (Extended data: Table S22) obtained from Hospital das Clínicas, Faculdade de Medicina da Universidade de São Paulo (HC-FMUSP), São Paulo, Brazil. The samples were amplified by multiplex PCR and only those amplified and visible on agarose gel were sequenced. From these, samples with a range of Ct-values were selected for SMART-9N and Rapid SMART-9N sequencing (Extended data: Table $\mathrm{S}^{22}$ );

- Ten residual nasopharyngeal samples previously positive for SARS-CoV-2 by RT-qPCR ${ }^{24}$, collected between November 17, 2020, and January 05, 2021, with Ct-values $\leq 34$, obtained from the Instituto de Medicina Tropical, Faculdade de Medicina da Universidade de São Paulo, Brazil (Extended data: Table S2). These samples were selected for multiplex PCR and Rapid SMART-9N sequencing (Extended data: Table $\mathrm{S}^{22}$ ).

Participants or their legal representatives provided signed informed consent. The ethical overview was provided by the institutional review boards at HC-USP and the Infectious 
Diseases Institute "Emilio Ribas" for the YFV study. For the SARS-CoV-2 study, ethical approval was by the national ethical review board (Comissão Nacional de Ética em Pesquisa), protocol number CAAE 30127020.0.0000.0068.

\section{Nucleic acid extraction and RT-qPCR testing}

Samples were centrifuged for 5 minutes at $10,000 \mathrm{xg}$. For the ZIKV isolate, the viral RNA was isolated from $200 \mu \mathrm{l}$ of the recovered material using the QIAamp Viral RNA Mini Kit (Cat No. 52906, Qiagen, Germany) according to the manufacturer's instructions and eluting in $50 \mu \mathrm{l}$ of elution buffer. For the SARS-CoV-2 nasopharyngeal and YFV plasma samples, the viral RNA was extracted from $200 \mu \mathrm{l}$ of material using the NucliSENS EasyMag system (BioMerieux, UK) automated DNA/RNA extraction platform, and eluted in $50 \mu \mathrm{l}$. Ct-values were previously determined for all samples by RT-qPCR for $\mathrm{ZIKV}^{20}, \mathrm{YFV}^{23}$, and SARS-CoV-2 ${ }^{24}$.

The extracted RNA was treated using TURBO DNase (Cat No. AM2239, Thermo Fisher Scientific, USA) at $37^{\circ} \mathrm{C}$ for $30 \mathrm{~min}$ to remove residual DNA before being cleaned up and concentrated to $10 \mu \mathrm{l}$ using Zymo RNA clean \& concentrator-5 (Cat No. R1016, Zymo Research, USA).

\section{Multiplex tiling PCR}

cDNA synthesis and Multiplex PCR. Samples were submitted to whole-genome sequencing using a gold-standard multiplex PCR amplicon sequencing approach ${ }^{19}$. Briefly, the cDNA was produced from RNA-positive samples using random hexamers (Cat No. N8080127, Thermo Fisher Scientific, USA) and ProtoScript II reverse transcriptase (Cat No. E6560, New England BioLabs, USA) according to the manufacturer's instructions. The cDNA was then amplified with the multiplex PCR assay previously standardized for ZIKV, $\mathrm{YFV}^{9,19}$, and with the ARTIC V3 multiplexed amplicon scheme for SARS-CoV-2 ${ }^{25}$ (https://artic.network/ncov-2019). PCR products were purified using a 1:1 ratio of AMPure XP beads (Cat No. A63881, Beckman Coulter, UK) and quantified using fluorimetry with the Qubit dsDNA High Sensitivity Assay (Cat No. Q32854, Life Technologies, USA) on the Qubit 3.0 instrument (Life Technologies, USA) both according to manufacturer's instructions. A gel was prepared with the PCR products using the E-gel Agarose 2\% (Cat No. G402002, Thermo Fisher Scientific, USA) on E-gel equipment (Thermo Fisher Scientific, USA) and the run was performed until the bands were distinguishable by transillumination. The samples that presented specific bands were selected for MinION sequencing.

Nanopore library preparation and sequencing. MinION libraries were prepared using a total input of $100 \mathrm{ng}$, barcoded, and pooled in an equimolar fashion using the EXP-NBD104 (1-12), and EXP-NBD114 (13-24) Native Barcoding Kits (ONT, UK). Sequencing libraries were generated using the SQK-LSK109 Kit (ONT, UK). 20 ng of the final libraries were loaded onto FLO-MIN106 flow cells on the MinION device (ONT, UK) and sequenced using MinKNOW 1.15.1 with the standard 48-hour run script.

\section{SMART-9N}

SMART cDNA synthesis and PCR. For the SMART-9N cDNA synthesis, $10 \mu \mathrm{l}$ of the concentrated RNA, $1 \mu \mathrm{l}$ NEB-RT tagged 9N (AAGCAGTGGTATCAACGCAGAGTACNNNNNNNNN, $2 \mu \mathrm{M})$ and $1 \mu \mathrm{l} 10 \mathrm{mM}$ deoxyribonucleotide triphosphate (dNTPs) mix (Cat No. N0447L, New England Biolabs, USA) were mixed and incubated for $5 \mathrm{~min}$ at $65^{\circ} \mathrm{C}$, then cooled on ice. $4 \mu \mathrm{l}$ SuperScript IV first-strand buffer, $1 \mu \mathrm{L}$ 0.1 M DTT, $1 \mu \mathrm{l}$ RNase OUT, $1 \mu$ l NEB-SSP (RNA oligo) (GCTAATCATTGCAAGCAGTGGTATCAACGCAGAGTACATrGrGrG, $2 \mu \mathrm{M})$, and $1 \mu \mathrm{L}$ SuperScript IV (Cat No. 18091200, Thermo Fisher Scientific, USA) were mixed with the $12 \mu \mathrm{l}$ annealed RNA before incubation for $90 \mathrm{~min}$ at $42^{\circ} \mathrm{C}$ followed by $10 \mathrm{~min}$ at $70^{\circ} \mathrm{C}$. These double-tagged cDNA products were amplified using $5 \mu \mathrm{l}$ Q5 reaction buffer (Cat No. M0491, New England BioLabs, USA), $0.5 \mu \mathrm{l} \quad 10 \mu \mathrm{M} \quad \mathrm{dNTP}, \quad 1 \mu \mathrm{l}$ NEB-PCR (AAGCAGTGGTATCAACGCAGAGT, $20 \mu \mathrm{M}$ ), $\quad 15,75 \quad \mu \mathrm{l}$ Nuclease-free water (NFW), 0,25 $\mu \mathrm{l}$ Q5 DNA polymerase, and $2,5 \mu \mathrm{l}$ of cDNA. PCR cycling conditions were: $98^{\circ} \mathrm{C}$ for 45 sec, followed by 30 cycles of $98^{\circ} \mathrm{C}$ for $15 \mathrm{sec}, 62^{\circ} \mathrm{C}$ for $15 \mathrm{sec}$, and $65^{\circ} \mathrm{C}$ for $5 \mathrm{~min}$ and a final step of $65^{\circ} \mathrm{C}$ for $10 \mathrm{~min}$. The products were purified using a 1:1 ratio of AMPure XP beads (Cat No. A63881, Beckman Coulter, UK) and quantified using fluorometry with the Qubit dsDNA High Sensitivity assay (Cat No. Q32854, Life Technologies, USA) on the Qubit 3.0 instrument (Life Technologies, USA) both according to manufacturer's instructions.

Nanopore library preparation and sequencing. MinION libraries were prepared using $50 \mathrm{ng}$ of each amplified cDNA, barcoded, and pooled in an equimolar fashion using the EXP-NBD104 (1-12) and EXP-NBD114 (13-24) Native Barcoding Kits (ONT, UK). Sequencing libraries were generated using the SQK-LSK109 Kit. $50 \mathrm{ng}$ of the final libraries were loaded onto FLO-MIN106 flow cells on the MinION device (ONT, UK) and sequenced using MinKNOW 1.15.1 with the standard 48-hour run script.

\section{Rapid SMART-9N}

SMART cDNA synthesis and barcoded PCR. For the rapid SMART-9N cDNA synthesis, $10 \mu \mathrm{l}$ of the concentrated RNA, $1 \mu$ RLB RT tagged 9N (TTTTTCGTGCGCCGCTTCAACNNNNNNNNN, $2 \mu \mathrm{M}$ ) and $1 \mu \mathrm{l} 10 \mathrm{mM}$ dNTPs (Cat No. N0447L, New England BioLabs, USA) were mixed and incubated for $5 \mathrm{~min}$ at $65^{\circ} \mathrm{C}$, then cooled on ice. $4 \mu \mathrm{l}$ SuperScript IV First-strand Buffer, $1 \mu \mathrm{L} 0.1$ M DTT, $1 \mu \mathrm{l}$ RNase OUT, $1 \mu$ RLB TSO (RNA oligo) (GCTAATCATTGCTTTTTCGTGCGCCGCTTCAACATrGrGrG, $2 \mu \mathrm{M}$ ), and $1 \mu \mathrm{L}$ SuperScript IV (Cat No. 18091200, Thermo Fisher Scientific, USA) was mixed with the $12 \mu \mathrm{l}$ annealed RNA before incubation for $90 \mathrm{~min}$ at $42^{\circ} \mathrm{C}$ followed by $10 \mathrm{~min}$ at $70^{\circ} \mathrm{C}$. These double-tagged cDNA products were amplified using $25 \mu \mathrm{l}$ LongAmp Taq $2 \mathrm{X}$ master mix (Cat No. M0287, New England BioLabs, USA), $19.5 \mu \mathrm{l}$ of NFW, $0.5 \mu \mathrm{l}$ RLB (1-12) from SQK-RPB004 kit (ONT, UK) and $5 \mu \mathrm{l}$ of cDNA. PCR cycling conditions were: $95^{\circ} \mathrm{C}$ for $45 \mathrm{sec}$, followed by $25-30$ cycles of $95^{\circ} \mathrm{C}$ for $15 \mathrm{sec}$, $56^{\circ} \mathrm{C}$ for $15 \mathrm{sec}$, and $65^{\circ} \mathrm{C}$ for $5 \mathrm{~min}$ and a final step of $65^{\circ} \mathrm{C}$ 
for $10 \mathrm{~min}$. For the PCR step, the RLB PCR (TTTTTCGTGCGCCGCTTCA, $20 \mu \mathrm{M}$ ) can be used as PCR control, changing the cycles conditions to $98^{\circ} \mathrm{C}$ for $45 \mathrm{sec}$, followed by $25-30$ cycles of $98^{\circ} \mathrm{C}$ for $15 \mathrm{sec}, 62^{\circ} \mathrm{C}$ for $15 \mathrm{sec}$, and $65^{\circ} \mathrm{C}$ for $5 \mathrm{~min}$ and a final step of $65^{\circ} \mathrm{C}$ for $10 \mathrm{~min}$. The products were purified using a 1:1 ratio of AMPure XP beads (Cat No. A63881, Beckman Coulter, UK), quantified using fluorimetry with the Qubit dsDNA High Sensitivity Assay (Cat No. Q32854, Life Technologies, USA) on the Qubit 3.0 instrument (Life Technologies, USA) both according to manufacturer's instructions.

Nanopore library preparation and sequencing. MinION libraries were prepared using $50 \mathrm{ng}$ of each amplified cDNA, pooled in an equimolar fashion of $400 \mathrm{ng}$ in $10 \mu \mathrm{l}$ of $10 \mathrm{mM}$ Tris- $\mathrm{HCl} \mathrm{pH} 8.0$ with $50 \mathrm{mM} \mathrm{NaCl}$. $1 \mu$ RAP adapter was added to the library and incubated at room temperature for $5 \mathrm{~min}$. $50 \mathrm{ng}$ of the final libraries were loaded onto FLO-MIN106 flow cells on the MinION device (ONT, UK) and sequenced using MinKNOW 1.15.1 with the standard 48-hour run script.

\section{Bioinformatics workflow}

Raw FAST5 files were basecalled using Guppy software version 2.2.7 GPU basecaller (Oxford Nanopore Technologies), then demultiplexed and trimmed using Porechop v.0.3.2pre. The barcoded FASTQ files were aligned and mapped to the reference genome (GenBank accession no. JF912190 (YFV), KX893855.1 (ZIKV), and MN908947 (SARS-CoV-2)) using minimap2 version 2.28.0 and converted to a sorted BAM file using SAMtools ${ }^{26}$. NanoStat version 1.1.2 was used to compute the number of raw reads and minimum contig length to cover 50 percent of the genome (N50) of the aligned reads. Tablet 1.19.05.28 27 was used for genome visualization, and to compute the number of mapped reads, percentage of genome coverage, and coverage depth. samtools stats and samtools depth ${ }^{26}$ were used to calculate longest reads and genome coverage at $20 \mathrm{x}$ respectively. For the multiplex PCR analysis, length filtering, quality test, and primmer trimming were performed for each barcode using artic guppyplex and variant calling and consensus sequences using artic minion Nanopolish version from ARTIC bioinformatics pipeline. For the SMART-9N and Rapid SMART-9N, called variants were detected with medaka_variants and the consensus sequence was built using medaka_consensus (ONT, UK).

For detection of other viral RNA in the clinical samples, taxonomic classification was conducted using Kraken version 2.0.8-beta ${ }^{28}$, using the MiniKraken2_v1_8GB Kraken 2 Database.

\section{Results}

In this study, we designed two methodologies, SMART-9N and Rapid SMART-9N. The SMART-9N approach is based on the NEBNext Single-cell/low-input RNA (cat No. E6420, New England BioLabs, USA) modified to use random priming and native barcoding library preparation (ONT, UK). The NEB method uses single-primer PCR amplification which we found we could perform using barcoded primers from the Rapid PCR Barcoding Kit (ONT, UK) if we modified the sequence of the RT and SSP oligos. This approach allows for amplification of RNA in the picogram input range (data not shown) making it ideal for low-input applications. We compared the complexity, costs, and time required of laboratory work to a previously standardized multiplex tilling PCR approach ${ }^{20}$. Compared to multiplex PCR, the total time of hands-on laboratory work dropped $15 \%$ and $61 \%$ for the SMART-9N and Rapid SMART-9N respectively, and reagent costs were reduced by $40 \%$ and $45 \%$ (Figure 1 ).
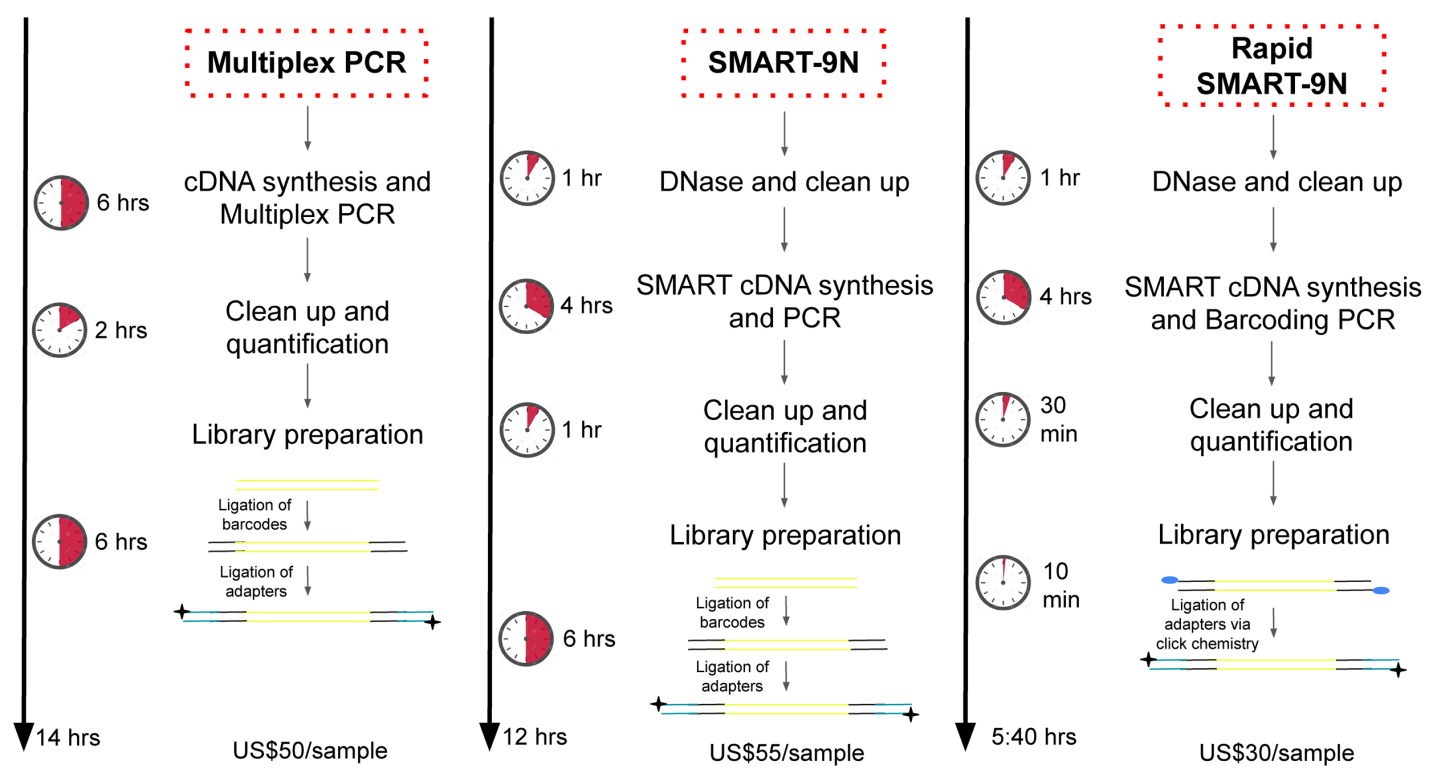

Figure 1. Comparison between the steps and cost of the workflows - tiling amplicon sequencing - Multiplex PCR, SMART-9N, and Rapid SMART-9N. Abbreviations: SSP: Strand Switching Primer. US\$, American dollar. 
Multiplex PCR sequencing of ZIKV isolate and YFV and SARS-CoV-2 clinical samples

Initial testing was performed on a serial dilution of ZIKV isolate, which was subjected to the gold-standard multiplex PCR approach followed by MinION sequencing ${ }^{19}$. This sample had a Ct-value of 15.1 and an RNA titer of $6 \mathrm{e} 07 \mathrm{FFU} / \mathrm{mL}$ (Extended data: Table $\mathrm{S}^{22}$ ). The percentage of mapped reads was $55.99 \%$ with an average depth of $326.98 x$ covering $98.74 \%$ of the viral genome covered with at least 1 read (Extended data: Table S3; Figure $2^{22}$ ).

The assay was also performed on 41 human clinical samples positive for YFV RNA by RT-qPCR from the 2018 YFV epidemic in São Paulo, Brazil. The median Ct-value was 27.74 , ranging from 4.6 to 37 corresponding to $1.00 \mathrm{e} 00$ to $1.50 \mathrm{e} 10$ genome copies per $\mathrm{mL}$ of plasma $^{29}$. After PCR product quantification and the E-gel agarose gel run, 21 samples presented specific bands distinguishable by transillumination and were selected to continue nanopore library preparation and sequencing (Extended data: Table $\left.\mathrm{S}^{22}\right)$. The sequenced $\mathrm{YFV}$ samples $(\mathrm{n}=21)$ had a median Ct-values $=25.57$, between 5 and 37 generated in one 24 barcoded library. The percentage of mapped reads ranged from $1.71 \%$ to $97.47 \%$, with an average depth between $72.50 x$ to $3370 x$, and the majority samples with genome coverage around $99.82 \%$ being the lowest $78.11 \%$ (Extended data: Table S3; Figure $3^{22}$ ). Genome regions with a depth of $<20 x$ coverage were represented with $\mathrm{N}$ characters.

For SARS-CoV-2 the assay was performed in 10 residual nasopharyngeal samples positive for SARS-CoV-2 RNA by RT-qPCR in April 2020 in São Paulo, Brazil. The median Ct-value was 26.9, ranging from 21.8 to 33.3 corresponding to $2.40 \mathrm{e} 05$ to $1.30 \mathrm{e} 02$ genome copies per $\mathrm{mL}$. The percentage of mapped reads ranged from $94.51 \%$ to $97.27 \%$, with an average depth between $821.77 \mathrm{x}$ to $1570 \mathrm{x}$, and genome coverage median of $98.8 \%$, ranging from $95.90 \%$ to 99.92\% (Extended data: Table S3; Figure 422).

SMART-9N and Rapid SMART-9N of ZIKV isolated-culture samples and limit of detection

For ZIKV, the titrated isolate RNA was diluted with serial ten-fold dilutions, up to $1: 1,000,000$ corresponding to $6 \mathrm{e} 07$ to 6e00 FFU/mL, and submitted to SMART-9N (Extended data: Table $\mathrm{S}^{22}$ ). The test resulted in a median of $99.7 \%$ genomic coverage for the tested dilutions with the lowest $99.02 \%$ for the $1: 1,000,000$ dilution. The percentage of genome coverage at $20 \mathrm{x}$ was $90.70 \%$ with $6 \mathrm{e} 00 \mathrm{FFU} / \mathrm{mL}$ up to $99.73 \%$ with $6 \mathrm{e} 07 \mathrm{FFU} / \mathrm{mL}$ of material input. The coverage depth was up to $10010 \mathrm{x}$, and $154.25 \mathrm{x}$ with $6 \mathrm{e} 00 \mathrm{FFU} / \mathrm{mL}$ of material, compatible with single-cell assays. The average of mapped reads ranged from $56.29 \%$ to $0.52 \%$. The median $\mathrm{N} 50$ was $1.7 \mathrm{~kb}$ and when the readings were individually analysed, the test obtained complete ZIKV genome covers in a single read (approximately $11 \mathrm{~Kb}$ longest read) (Figure 2).

The same 1:1,000,000 dilution was used to test the Rapid SMART-9N approach. The lowest proportions of mapped reads observed were $0.06 \%$ and the highest $86.15 \%$. The majority of samples returned a percentage of $99.87 \%$, with $87.58 \%$ for the $6 \mathrm{e} 00 \mathrm{FFU} / \mathrm{mL}$ dilution test. The median of the percentage of genome coverage at $20 \mathrm{x}$ was $90.73 \%$ and the N50 2.27kb (Figure 2).

The method was performed using $1 \mu \mathrm{l}$ and $0.5 \mu \mathrm{l}$ RLB barcodes from the SQK-RPB004 kit (ONT) with $6 \mathrm{e} 07$ of material input. The test resulted in $99.7 \%$ genomic coverage for both $1 \mu \mathrm{l}$ and $0.5 \mu \mathrm{l}$, and N50 of $1.84 \mathrm{~kb}$ and $2.11 \mathrm{~kb}$ respectively (Extended data: Table $\mathrm{S}^{22}$ ).

SMART-9N and Rapid SMART-9N of YFV clinical samples After validating the methods on ZIKV isolate we next applied them to clinical samples. Starting with the SMART-9N, seven representative human clinical samples positive for YFV RNA, already sequenced with the multiplex PCR method, with Ct-values between 4.6 and 33 were selected (Extended data: Table $\mathrm{S}^{22}$ ). A total of $86 \%$ of the samples presented genome coverage greater than $99.9 \%$ ranging from $95.11 \%$ to $99.99 \%$ with Ct-values of 33 and 18 respectively, and a minimum average depth of $3.2 x$, and a maximum of 3480x (Figure 3A). The same samples were selected and subjected to the Rapid SMART-9N method (Extended data: Table S722). The highest mapped read percentages observed were $98.26 \%$ and $38.18 \%$ for Ct-values 4.6 and 17.4, respectively. A total of $86 \%$ of the samples presented genome coverage greater than $99.9 \%$ with the lowest of $94.28 \%$ with a $\mathrm{Ct}$ of 33 , and the average depth ranged from $21.44 \mathrm{x}$ to $2530 \mathrm{x}$ (Figure $3 \mathrm{~A}$ ). We compared the coverage depth with different Ct-values samples across the relevant genome for each method (multiplex PCR, SMART-9N, and Rapid SMART-9N) (Extended data: Figure $\mathrm{S}^{22}$ ). The average coverage depth revealed higher genome depth and better coverage pattern across the genome for the metagenomics methods when compared to the multiplex PCR method.

All the seven sequenced samples with both methods were compared to the multiplex results. Despite the decrease in the proportion of mapped viral reads across the range of Ct-values (Figure 3B) with the SMART-9N and Rapid SMART-9N, we could obtain a comparable correlation (SMART-9N R=0.91, $\mathrm{p}=0.005$; Rapid SMART-Metagenomics $\mathrm{R}=-0.86, \mathrm{p}=0.012$,). The correlation showed a decreased proportion of viral reads as the Ct-values increased, with a considerable level of variation $(0.3 \%$ to $98.6 \%$ with SMART-9N and $0.16 \%$ to $98.26 \%$ with Rapid SMART-9N method) between samples and methods (Extended data: Tables S6 and $\mathrm{S} 7{ }^{22}$ ).

Comparable genome coverage 20-fold across the Ct-values between all methods is presented in Figure 3B. In the multiplex approach, the average of the genome coverage was $78.9 \%$ with a minimum of $35.01 \%$ for $\mathrm{Ct} 33$ compared to $71.5 \%$ and $89.3 \%$ for SMART-9N and Rapid SMART-9N with a minimum of $0 \%$ and $50.5 \%$, respectively (Extended data: Tables $\mathrm{S} 6$ and $\mathrm{S} 7^{22}$ ). 

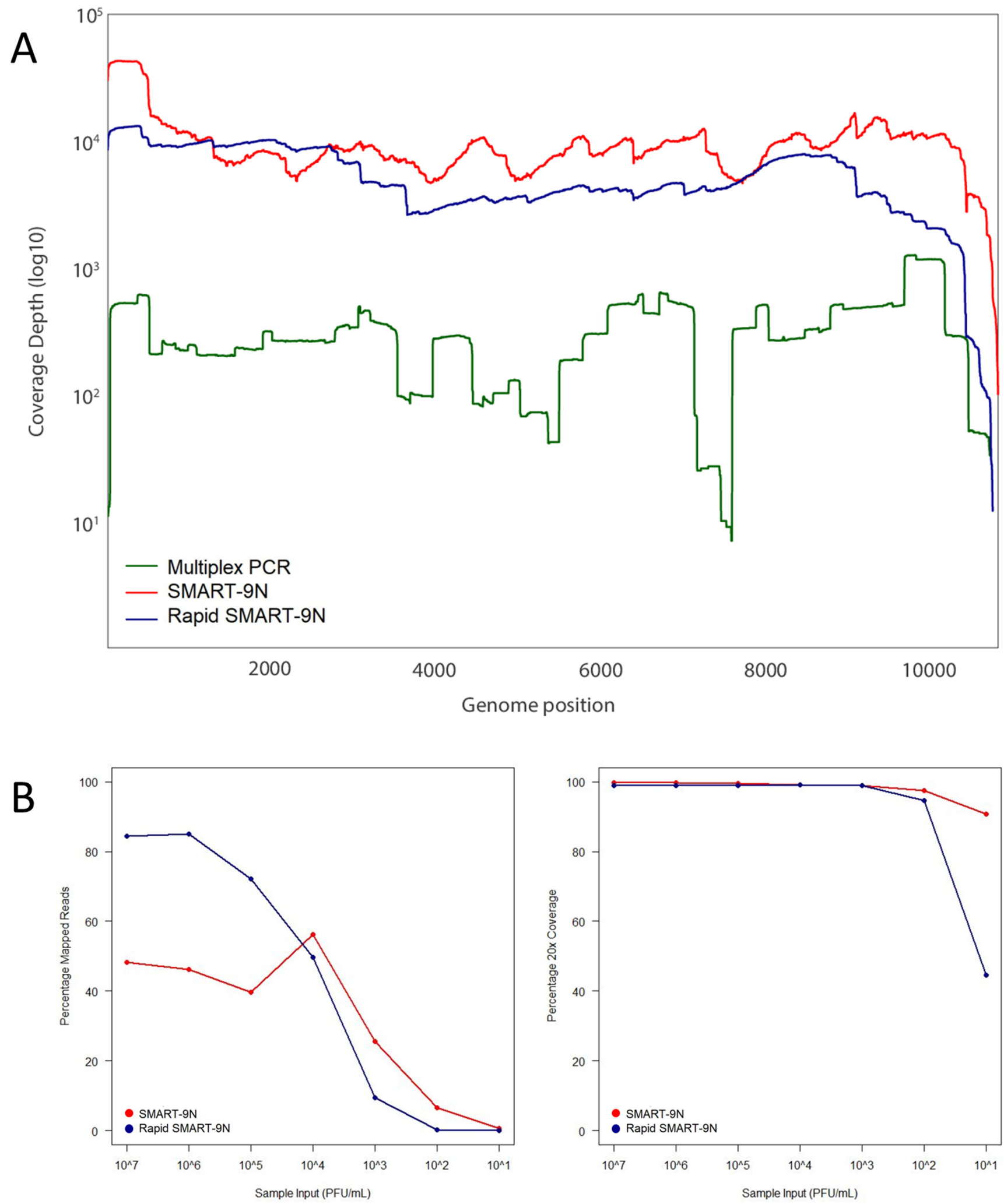

Figure 2. Comparison of multiplex PCR, SMART-9N, and Rapid SMART-9N approaches. A) Genome coverage of ZIKV genome for reference material as to coverage of reads mapped to the genome reference position comparing the multiplex PCR, SMART-9N, and Rapid SMART-9N approaches. B) Limit of detection of the SMART-9N and Rapid SMART-9N methods analyzing the proportions of reads mapping to the appropriate reference viral sequence across a range of sample input (FFU/mL) on the left plot and percentage of the reference genome sequenced to a minimum depth of 20 -fold in the data generated across a range of sample input (FFU/mL) on the right plot. 

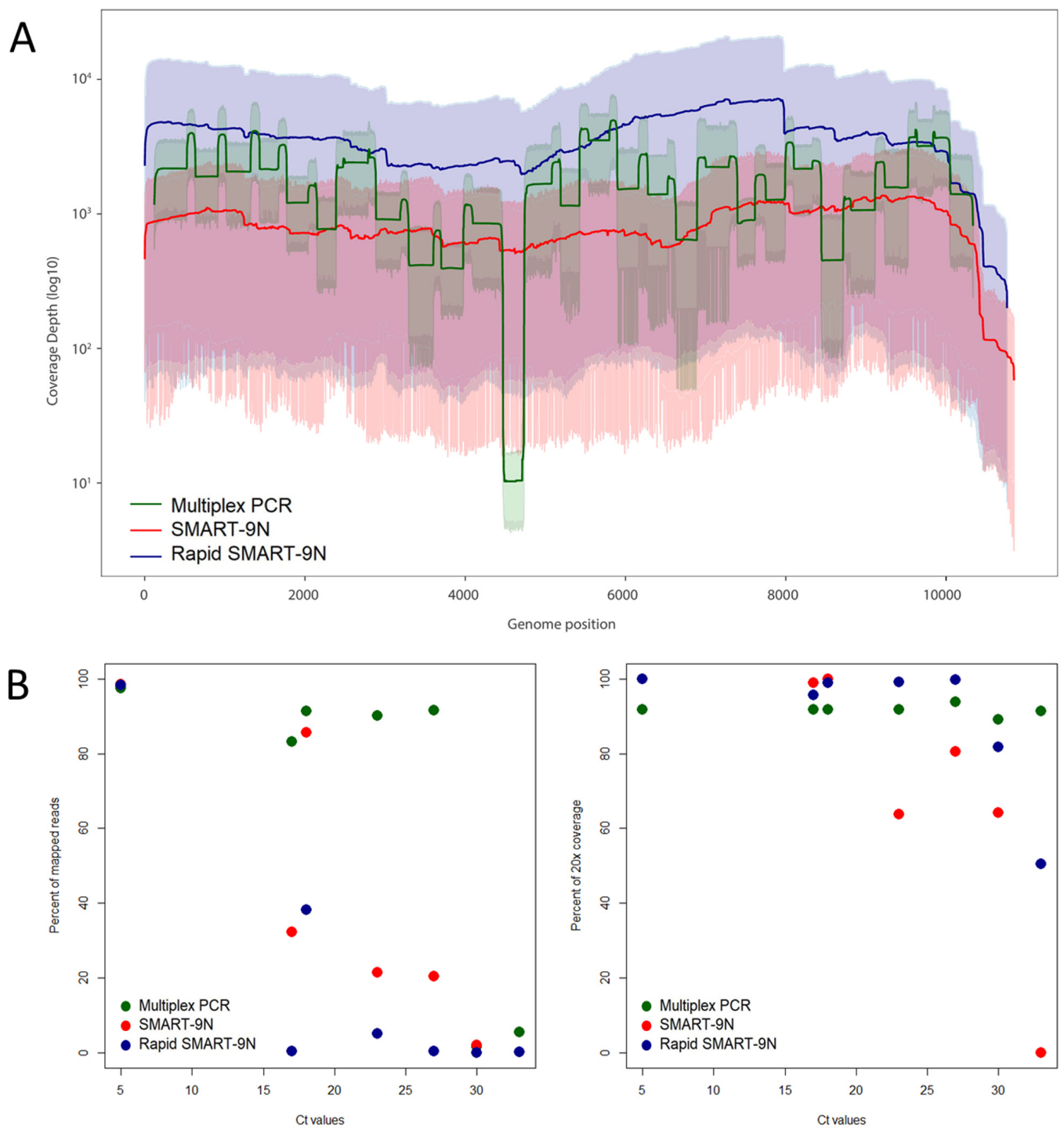

C

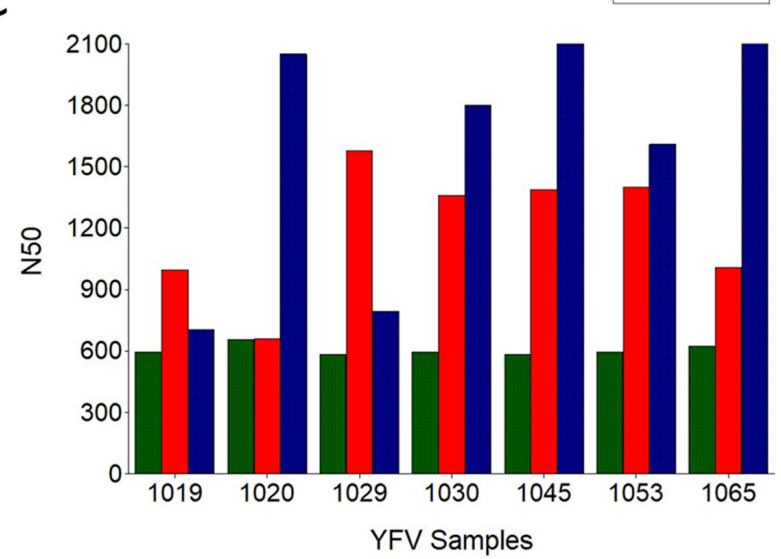

Figure 3. Comparison of multiplex PCR, SMART-9N, and Rapid SMART-9N results for YFV clinical samples. A) Average genome coverage depth and 95\% of reads mapped to the genome reference position. B) Proportion of reads mapping to the reference genome across a range of Ct-values (left) and percentage of the reference genome sequenced to a minimum depth of 20-fold across a range of Ct-values (right). C) N50 of each sample in bp. ( $n=7$ samples). 

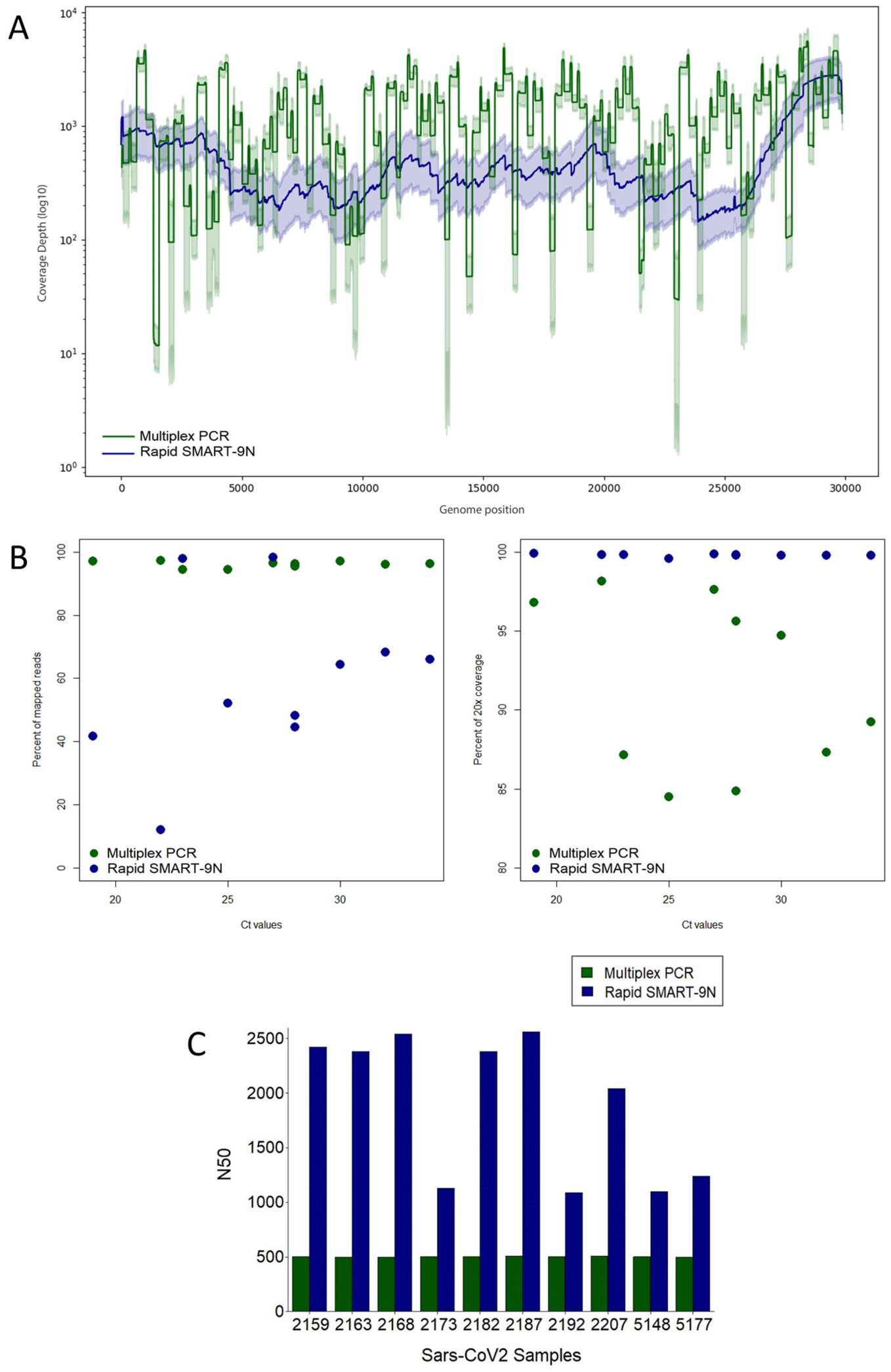

Figure 4. Comparison of multiplex PCR, and Rapid SMART-9N results for SARS-CoV-2 clinical samples. A) Average genome coverage depth and $95 \%$ of reads mapped to the genome reference position. B) Proportion of reads mapping to the reference genome across a range of Ct-values (left) and percentage of the reference genome sequenced to a minimum depth of 20-fold across a range of Ct-values (right). C) N50 of each sample in bp. ( $n=10$ samples). 
For this subset of samples, we also compared the N50 results from the approaches for each sample (Figure 3C). Here we found the range was $525 \mathrm{bp}$ to $660 \mathrm{bp}$ for multiplex PCR, $659 \mathrm{bp}$ to $1.58 \mathrm{kbp}$ for SMART-9N, $705 \mathrm{bp}$ to $2.16 \mathrm{~kb}$ for Rapid SMART-9N. The median was $599.8 \mathrm{bp}, 1.6 \mathrm{kbp}$, and $1.2 \mathrm{kbp}$ for the multiplex PCR, SMART-9N, and Rapid SMART-9N respectively (Extended data: Tables $\mathrm{S} 6$ and $\mathrm{S}^{22}$ ). For the YFV clinical samples, the longest reads observed were $10.08 \mathrm{~kb}$ and $9.12 \mathrm{~kb}$ for the SMART-9N, and Rapid SMART-9N, respectively $93.33 \%$ and $84.44 \%$ of the entire viral genome.

\section{Rapid SMART-9N of SARS-CoV-2 clinical samples}

SARS-CoV-2 clinical samples were subjected to the Rapid SMART-9N approach. Reads mapping to reference virus genome (isolate: Wuhan-Hu-1, GenBank Accession No. MN908947) were present in all ten seven samples up to Ct-value 34 (total reads ranged from 6480 to 93,570 reads). The sequenced samples were compared to the multiplex results and did not show a significant correlation ( $R=0.49$, $\mathrm{p}=0.15$ ) between the proportion of viral reads with increasing Ct-value (12.15 - 98.22\%) (Extended data: Table $\mathrm{S} 8^{22}$ ). The genome coverage was $100 \%$ in all 7 samples and the lowest coverage depth of 97.51x (Figure 4A). When comparing each coverage depth across different Ct-values samples for the multiplex PCR, and Rapid SMART-9n methods (Extended data: Figure S2 ${ }^{22}$ ), we could observe a concordant coverage depth and coverage pattern across the genome for both methods.

Comparison of genome coverage 20-fold between multiplex PCR and Rapid SMART-9N across the viral titer range is shown in Figure 4B. The median revealed was $91.59 \%$, minimum 84.49\%, and the Rapid SMART-9N 99.79\%, minimum of $99.57 \%$. A comparison of the $\mathrm{N} 50$ in all the 10 samples was made resulting in a higher N50 of all samples to the Rapid SMART-9N approach, up to $2.56 \mathrm{~kb}$. The longest read was $18.48 \mathrm{~kb}$, the longest read obtained in this study, comprising approximately $62 \%$ of the SARS-CoV-2 genome (29,903 bp) (Figure 4C).

\section{Detection of other RNA viruses in clinical samples and Kraken classification}

To test the ability of our methods to detect other viruses in our samples, we assessed the taxonomic classification of reads using Kraken for all clinical samples. This allowed for the identification of a dsDNA virus genus Pa6virus, family Siphoviridae present in one YFV sample. After identification, the reads were mapped to the reference sequence (NC_018838.1) obtaining 197 reads of the virus, $84.78 \%$ of genome coverage with a maximum coverage depth of $32 \mathrm{x}$, and identity of $81.4 \%$. The consensus sequence was generated and bases with a depth of $<10$-fold were represented with $\mathrm{N}$ characters (github.com/CADDE-CENTRE/Rapid-RNASMART-Metagenomics). The proportion of unclassified, eukaryota, bacteria, archaea, and viruses reads, for each sample can be found in the Extended data, Table $\mathrm{S}^{22}$.

\section{Discussion}

A rapid, sensitive sequencing method for viral metagenomics is key to be able to identify the cause of unknown infections. Although PCR-based testing and amplicon-based sequencing methodologies are available and very sensitive, they are not suitable for the initial detection of emerging or re-emerging viruses due to the need for gene-specific primers/probes for diagnostic assays or primer panels ${ }^{15}$. The aetiology of suspected infections in acute illness often remains undiagnosed. An untargeted sequencing method remains the best strategy for the identification of unknown viral infections, and the genome sequences provide information about the evolutionary history $^{30}$, strain identification ${ }^{31,32}$, and biology of new pathogens ${ }^{33}$. This is evidenced by the recent rapid and impactful metagenomic analysis of SARS-CoV-2 early in the pandemic ${ }^{34,35}$

In this study, we developed two viral metagenomic approaches, SMART-9N and Rapid SMART-9N as non-targeted metagenomics methods for detection and characterization of viral RNA. The two techniques demonstrated excellent specificity (100\%) when tested in isolated and clinical samples that had been compared to a gold-standard multiplex PCR method ${ }^{5-9}$ and allowed the identification of an unknown co-infection in a YFV clinical sample. For ZIKV isolated-culture, it was possible to obtain $99.02 \%$ of genome coverage with an input of $6 \mathrm{e} 00 \mathrm{FFU} / \mathrm{mL}$, an amount comparable to other single-cell methods available ${ }^{36,37}$ for the SMART-9N approach. For the Rapid SMART-9N, $87.58 \%$ of the ZIKV genome was recovered for the same dilution of $1: 1,000,000$, equivalent to $6 \mathrm{e} 00 \mathrm{FFU} / \mathrm{mL}$. The sensitivity and high yield of viral sequences from clinical YFV and SARS-CoV-2 samples make it potentially feasible to directly perform metagenomic MinION whole-genome sequencing, even for higher Ct-values. Representative clinical samples with Ct-values between 4.6 and 33 for $\mathrm{YFV}$, and between 21.8 and 33.3 for SARS-CoV-2 were selected to test the genome recovery for the viruses tested. Notably, the SMART-9N and Rapid SMART-9N methods were effective in directly genome sequencing clinical samples for both viruses tested since viral reads were detected in all samples, until in samples with $1.00 \mathrm{e} 00$ genome copy per $\mathrm{mL}$.

Evaluating the read length during the validation, we observed that our approach generated very long reads when compared to other metagenomics approaches ${ }^{16,17}$. In this study, we generated the whole ZIKV and YFV genome and approximately $60 \%$ of the SARS-CoV-2 genome in one single read. The N50 of the methods was up to $2.91 \mathrm{~kb}$ with the isolated samples and up to $2.56 \mathrm{~kb}$ with SARS-CoV-2 clinical samples and the Rapid SMART-9N approach. When looking at the average coverage depth and the CI of the metagenomics methods, we could observe a consistent amplification across the entire genomes due to this high N50 generated for the methods. Increased N50 provides higher confidence in individual read taxonomic assignment, improves mapping confidence, de novo assembly, and the ability to detect viral 
recombinations ${ }^{38,39}$. To our knowledge $18.5 \mathrm{~kb}$ is the longest viral cDNA published to date produced by the Rapid SMART-9N method, this was likely due to the fact that LongAmp polymerase is used for barcoded primers as per ONT recommendations whereas Q5 polymerase was used for SMART-9N.

We also compared the complexity, costs, and time required of laboratory work to the multiplex tilling PCR approach ${ }^{19}$. Using this approach, our Rapid SMART-9N reduced the complexity, time, and cost from sample to sequence. The possibility of barcode addition during PCR decreased the time of library preparation from 6 hours to 10 minutes, reducing the probability of laboratory error and the cost due to no longer needing enzymes for end-preparation and ligation which also rely on a cold chain making them inconvenient to use in the field. The total time of laboratory work dropped $15 \%$ and $61 \%$ for the SMART-9N and Rapid SMART-9N respectively when compared to the multiplex PCR. The costs when using Rapid SMART-9N dropped 45\% and $40 \%$ compared to SMART-9N and multiplex PCR respectively. Using half of the volume for the rapid barcode primers doubles the number of samples that can be processed with the kit. This protocol has the potential to be further optimized and used in a lyophilized formulation with the elimination of any cold chain. These results demonstrate that the Rapid SMART-9N is an important approach in both the laboratory or field settings.

\section{Limitations of the method}

The overwhelming majority of reads are derived from the human host, mainly in clinical samples with high Ct-values (with a low relative abundance of viral genomic material) or in samples with degraded genetic material, due to incorrect transport or long-term storage. This is a limiting factor of the analytical sensitivity of the approach for infectious agent detection that could result in insufficient sequencing depth of the organism of interest. This disadvantage is shown in our study when comparing the viral mapped reads of the ZIKV isolates to the YFV and SARS-CoV-2 clinical samples. The lower proportion of viral reads as the increase of the Ct-values is likely because of the total level of non-viral host/background nucleic acid present due to variability between patients or in sample handling during collection.

\section{Conclusion}

Here we demonstrate a sensitivity workflow across viral isolate and clinical samples which takes advantage of long-read nanopore sequencing technology by generating long (up to $18.5 \mathrm{~kb}$ ) cDNA amplification products for viral metagenomics. Therefore, our metagenomic sequencing approaches offer an opportunity for sensitive identification and characterization of RNA viruses directly from isolates or clinical samples with a range of viral loads. Also, the Rapid SMART-9N demonstrated a simple, low-cost, and faster method, promising for routine use in the research laboratory as well as in the field.

\section{Data availability}

\section{Underlying data}

Zenodo: CADDE-CENTRE/Rapid-RNA-SMART-Metagenomics: Release Rapid-SMART-9N, https://doi.org/10.5281/zenodo. $5391968^{22}$.

This project contains the following underlying data:

- SARS_CoV_2_CONSENSUS_SEQUENCES (SARS$\mathrm{CoV}-2$ consensus sequences $(\mathrm{n}=10)$ generated by multiplex PCR and Rapid SMART-9N methods).

- YFV_CONSENSUS_SEQUENCES (YFV consensus sequences $(n=7)$ generated by multiplex PCR, SMART-9N, and Rapid SMART-9N methods).

- ZIKV_CONSENSUS_SEQUENCES (ZIKV reference consensus sequences $(n=1)$ generated by multiplex PCR, SMART-9N, and Rapid SMART-9N methods).

- ZIKV_Multiplex_PCR_RAW_FILES (Raw data (fastq) of ZIKV, SARS-CoV-2, and YFV generated in this study).

\section{Extended data}

Zenodo: CADDE-CENTRE/Rapid-RNA-SMART-Metagenomics: Release Rapid-SMART-9N, https://doi.org/10.5281/ zenodo. $5391968^{22}$.

This project contains the following extended data within the file 'Supplementary_material_SMART_9N.pdf':

- Table S1 - Description of samples collected and protocol realized to each sample.

- Table S2 - Description of samples positive for Zika virus (ZIKV) reference sample strain BeH815744 (n=1), yellow fever virus (YFV) $(\mathrm{n}=41)$, and severe acute respiratory syndrome coronavirus 2 (SARS-CoV-2) $(\mathrm{n}=10)$ by real-time quantitative reverse transcription PCR with the corresponding sample types, Ct-values, estimated focus forming units (FFU) per milliliter or estimated genome copies per $\mathrm{mL}$, and the virus reference size (nts).

- Table S3 - Summary of virus nanopore sequencing data using the tiling multiplex PCR approach of Zika virus reference strain BeH815744 (ZIKV) $(n=1)$, yellow fever virus (YFV) $(n=21)$, and severe acute respiratory syndrome coronavirus 2 (SARS-CoV-2) $(n=10)$ samples with the corresponding $\mathrm{Ct}$-values.

- Table S4 - Sequencing summary and alignment statistics results for Zika vírus (ZIKV) reference sample strain BeH815744 using the SMART-9N method during development $(n=1$ sample) according to the material input $(\mathrm{FFU} / \mathrm{mL})$.

- Table S5 - Sequencing summary and alignment statistics results for Zika virus reference sample strain BeH815744 using the Rapid SMART-9N method during development $(\mathrm{n}=1$ sample) according to the material input (FFU/mL). 
- Table S6 - Sequencing summary and alignment statistics results for yellow fever virus (YFV) plasma samples $(n=7)$ using the SMART-9N protocol during method validation according to the $\mathrm{Ct}$-values.

- Table S7 - Sequencing summary and alignment statistics results for yellow fever virus (YFV) plasma samples $(n=7)$ using the Rapid SMART-9N protocol during method validation according to the Ct-values.

- Table S8- Sequencing summary and alignment statistics results for Severe acute respiratory syndrome coronavirus 2 (SARS-CoV-2) clinical samples $(n=10)$ using the Rapid SMART-9N protocol during method validation according to the $\mathrm{Ct}$-values.

- Table S9 - Proportion in the percentage of unclassified, Eukaryota, bacteria, archaea, and viruses reads, for each sample according to the Kraken classification distribution and metagenomics methodologies.

- Figure S1 - Comparison of genome coverage depth across the yellow fever virus (YFV) genome for different methods (i.e., multiplex PCR, SMART-9N, and Rapid SMART-9N) in all clinical samples tested with different Ct-values. YFV ( $\mathrm{n}=7$ )

- Figure S2 - Comparison of genome coverage depth across the Severe acute respiratory syndrome coronavirus 2 (SARS-CoV-2) virus genome for different methods (i.e., multiplex PCR, and Rapid SMART-9N) in all clinical samples tested with different Ct-values. SARS-CoV-2 $(\mathrm{n}=10)$.

Data are available under the terms of the Creative Commons Zero "No rights reserved" data waiver (CC0 1.0 Public domain dedication)

\section{Acknowledgments}

We thank the CADDE (Brazil-UK Centre for Arbovirus Discovery, Diagnosis, Genomics, and Epidemiology), ARTIC Network team, and the FAPESP and MRC foundation for the funding.
1. Devaux CA: Emerging and re-emerging viruses: A global challenge illustrated by Chikungunya virus outbreaks. World J Virol. 2012; 1(1): 11-22. PubMed Abstract | Publisher Full Text | Free Full Text

2. Miller S, Naccache SN, Samayoa E, et al.: Laboratory validation of a clinical metagenomic sequencing assay for pathogen detection in cerebrospinal fluid. Genome Res. 2019; 29(5): 831-842.

PubMed Abstract | Publisher Full Text | Free Full Text

3. Washington JA: Principles of Diagnosis. Chapter 10. In: Baron S, editor. Medical Microbiology. 4th edition. Galveston (TX): University of Texas Medical Branch at Galveston; 1996.

Reference Source

4. Wilson MR, Naccache SN, Samayoa E, et al.: Actionable diagnosis of neuroleptospirosis by next-generation sequencing. N Engl J Med. 2014; 370(25): 2408-17.

PubMed Abstract | Publisher Full Text | Free Full Text

5. Quick J, Loman NJ, Duraffour S, et al.: Real-time, portable genome sequencing for Ebola surveillance. Nature. 2016; 530(7589): 228-232. PubMed Abstract | Publisher Full Text | Free Full Text

6. Faria NR, Quick J, Claro IM, et al.: Establishment and cryptic transmission of Zika virus in Brazil and the Americas. Nature. 2017; 546(7658): 406-410. PubMed Abstract | Publisher Full Text | Free Full Text

7. Naveca FG, Claro I, Giovanetti M, et al.: Genomic, epidemiological and digital surveillance of Chikungunya virus in the Brazilian Amazon. PLOS Negl Trop Dis. 2019; 13(3): e0007065.

PubMed Abstract | Publisher Full Text | Free Full Text

8. de Jesus JG, Dutra KR, Sales FCDS, et al.: Genomic detection of a virus lineage replacement event of dengue virus serotype 2 in Brazil, 2019. Mem Inst Oswaldo Cruz. 2020; 115: e190423.

PubMed Abstract | Publisher Full Text | Free Full Text

9. Faria NR, Kraemer MUG, Hill SC, et al.: Genomic and epidemiological monitoring of yellow fever virus transmission potential. Science. 2018; 361(6405): 894-899.

PubMed Abstract | Publisher Full Text | Free Full Text

10. Houldcroft CJ, Beale MA, Breuer J: Clinical and biological insights from viral genome sequencing. Nat Rev Microbiol. 2017; 15(3): 183-192. PubMed Abstract | Publisher Full Text | Free Full Text
11. Palacios $G$. Druce J. Du L et al: A new arenavirus in a cluster of fatal transplant-associated diseases. N Engl J Med. 2008; 358(10): 991-8. PubMed Abstract | Publisher Full Text

12. Nakamura S, Yang CS, Sakon N, et al.: Direct metagenomic detection of viral pathogens in nasal and fecal specimens using an unbiased highthroughput sequencing approach. PLoS One. 2009; 4(1): e4219. PubMed Abstract | Publisher Full Text | Free Full Text

13. Manso CF, Bibby DF, Mbisa JL: Efficient and unbiased metagenomic recovery of RNA virus genomes from human plasma samples. Sci Rep. 2017; 7(1): 4173.

PubMed Abstract | Publisher Full Text | Free Full Text

14. Gu W, Miller S, Chiu CY: Clinical Metagenomic Next-Generation Sequencing for Pathogen Detection. Annu Rev Pathol. 2019: 14: 319-338. PubMed Abstract | Publisher Full Text | Free Full Text

15. Frey KG, Herrera-Galeano JE, Redden CL, et al.: Comparison of three nextgeneration sequencing platforms for metagenomic sequencing and identification of pathogens in blood. BMC Genomics. 2014; 15: 96. PubMed Abstract | Publisher Full Text | Free Full Text

16. Kafetzopoulou LE, Efthymiadis K, Lewandowski K, et al.: Assessment of metagenomic Nanopore and Illumina sequencing for recovering whole genome sequences of chikungunya and dengue viruses directly from clinical samples. Euro Surveill. 2018; 23(50): 1800228. PubMed Abstract | Publisher Full Text | Free Full Text

17. Lewandowski K, Xu Y, Pullan ST, et al.: Metagenomic Nanopore Sequencing of Influenza Virus Direct from Clinical Respiratory Samples. J Clin Microbiol. 2019; 58(1): e00963-19. PubMed Abstract | Publisher Full Text | Free Full Text

18. Zhu YY, Machleder EM, Chenchik A, et al.: Reverse transcriptase template switching: a SMART approach for full-length CDNA library construction. Biotechniques. 2001; 30(4): 892-7. PubMed Abstract | Publisher Full Text

19. Quick J, Grubaugh ND, Pullan ST, et al.: Multiplex PCR method for MinION and Illumina sequencing of Zika and other virus genomes directly from clinical samples. Nat Protoc. 2017; 12(6): 1261-1276. PubMed Abstract | Publisher Full Text | Free Full Text

20. Lanciotti RS, Kosoy OL, Laven J, et al.: Genetic and serologic properties of 
Zika virus associated with an epidemic, Yap State, Micronesia, 2007. Emerg Infect Dis. 2008; 14(8): 1232-9.

PubMed Abstract | Publisher Full Text | Free Full Text

21. Silva-Filho JL, de Oliveira LG, Monteiro L, et al.: Gas6 drives Zika virus-induced neurological complications in humans and congenital syndrome in immunocompetent mice. Brain Behav Immun. 2021; S0889-1591(21)00298-1. PubMed Abstract | Publisher Full Text

22. CADDE CENTRE: CADDE-CENTRE/Rapid-RNA-SMART-Metagenomics: Release Rapid-SMART-9N. (V1.1.0). Zenodo. 2021. http://www.doi.org/10.5281/zenodo.5391968

23. Fischer C, Torres MC, Patel P, et al.: Lineage-Specific Real-Time RT-PCR for Yellow Fever Virus Outbreak Surveillance, Brazil. Emerg Infect Dis. 2017; 23(11): 1867-71.

PubMed Abstract | Publisher Full Text | Free Full Text

24. Corman VM, Landt O, Kaiser M, et al.: Detection of 2019 novel coronavirus (2019-nCoV) by real-time RT-PCR. Euro Surveill. 2020; 25(3): 2000045. PubMed Abstract | Publisher Full Text | Free Full Text

25. Tyson JR, James P, Stoddart D, et al.: Improvements to the ARTIC multiplex PCR method for SARS-CoV-2 genome sequencing using nanopore. bioRxiv. [Preprint]. 2020; 2020.09.04.283077.

PubMed Abstract | Publisher Full Text | Free Full Text

26. Li H, Handsaker B, Wysoker A, et al:: The Sequence Alignment/Map format and SAMtools. Bioinformatics. 2009; 25(16): 2078-9. PubMed Abstract | Publisher Full Text | Free Full Text

27. Milne I, Bayer M, Cardle $L$, et al.: Tablet--next generation sequence assembly visualization. Bioinformatics. 2010; 26(3): 401-2.

PubMed Abstract | Publisher Full Text | Free Full Text

28. Wood DE, Lu J, Langmead B: Improved metagenomic analysis with Kraken 2. Genome Biol. 2019; 20(1): 257

PubMed Abstract | Publisher Full Text | Free Full Text

29. Kallas EG, D'Elia Zanella LGFAB, Moreira CHV, et al.: Predictors of mortality in patients with yellow fever: an observational cohort study. Lancet Infect Dis. 2019; 19(7): 750-758.

PubMed Abstract | Publisher Full Text

30. Gire SK, Goba A, Andersen KG, et al.: Genomic surveillance elucidates Ebola virus origin and transmission during the 2014 outbreak. Science. 2014; 345(6202): 1369-72.

PubMed Abstract | Publisher Full Text | Free Full Text

31. Salipante SJ, SenGupta DJ, Cummings LA, et al.: Application of whole-genome sequencing for bacterial strain typing in molecular epidemiology. J Clin Microbiol. 2015; 53(4): 1072-9.

PubMed Abstract | Publisher Full Text | Free Full Text

32. Deurenberg RH, Bathoorn E, Chlebowicz MA, et al.: Application of next generation sequencing in clinical microbiology and infection prevention.J Biotechnol. 2017; 243: 16-24.

PubMed Abstract | Publisher Full Text

33. Gu W, Miller S, Chiu CY: Clinical Metagenomic Next-Generation Sequencing for Pathogen Detection. Annu Rev Pathol. 2019; 14: 319-338.

PubMed Abstract | Publisher Full Text | Free Full Text

34. Carbo EC, Sidorov IA, Zevenhoven-Dobbe JC, et al.: Coronavirus discovery by metagenomic sequencing: a tool for pandemic preparedness. J Clin Virol. 2020; 131: 104594.

PubMed Abstract | Publisher Full Text | Free Full Text

35. Zhou $P$, Yang XL, Wang XG, et al.: A pneumonia outbreak associated with a new coronavirus of probable bat origin. Nature. 2020; 579(7798): 270-273. PubMed Abstract | Publisher Full Text | Free Full Text

36. Nawy T: Single-cell sequencing. Nat Methods. 2014: 11(1): 18 PubMed Abstract | Publisher Full Text

37. Eberwine J, Sul JY, Bartfai T, et al.: The promise of single-cell sequencing. Nat Methods. 2014; 11(1): 25-7.

PubMed Abstract | Publisher Full Text

38. Stephens $Z$, Wang C, Iyer RK, et al.: Detection and visualization of complex structural variants from long reads. BMC Bioinformatics. 2018; 19(Suppl20): 508.

PubMed Abstract | Publisher Full Text | Free Full Text

39. Fuselli S, Baptista RP, Panziera A, et al.: A new hybrid approach for MHC genotyping: high-throughput NGS and long read MinION nanopore sequencing, with application to the non-model vertebrate Alpine chamois (Rupicapra rupicapra). Heredity (Edinb). 2018; 121(4): 293-303. PubMed Abstract | Publisher Full Text | Free Full Text 


\section{Open Peer Review}

\section{Current Peer Review Status: ? ?}

\section{Version 1}

Reviewer Report 03 October 2022

https://doi.org/10.21956/wellcomeopenres.18969.r52412

(c) 2022 D'arc Ferreira da Costa $M$. This is an open access peer review report distributed under the terms of the Creative Commons Attribution License, which permits unrestricted use, distribution, and reproduction in any medium, provided the original work is properly cited.

\section{Mirela D'arc Ferreira da Costa}

Instituto de Biologia, Departamento de Genética, Laboratório de Diversidade e Doenças Virais, Federal University of Rio de Janeiro, Rio de Janeiro, Brazil

The authors describes a improvement of the SMART approach published in 2001. They developed a rapid viral metagenomics test using initially a random priming for cDNA synthesis and then the SMART-9N barcoded amplification. I believe that it is a important work and should be indexed after a good grammar and concept revision. Some points that should be verified are listed below.

1. In "Introduction" section, it is not clear if the "random priming for cDNA synthesis followed by PCR amplification" refers to the SMART-9N methodology.

2. The ethical approval number for the YFV study is absent in the mean text.

3. The reagents concentration should be more clear in all steps. It is very important to allow replication of the method by others.

4. Some decimal values are incorrectly separated by commas (for example, $15,75 \mu l$ Nucleasefree water).

5. In "Bioinformatics workflow" section, it is necessary to introduce the citation of all softwares/tools used (for example, minimap2). Also, the duplicated brackets after SARS-CoV2 should be removed.

6. It is not clear why the "Clean up and quantification" step has a dramatic time reduction, specially between SMART-9N and Rapid SMART-9N methodologies.

7. In "Rapid SMART-9N of SARS-CoV-2 clinical samples" section, the phrase "were present in all ten seven samples" is not understandable.

8. It is not clear why the SMART-9N approach was not performed to the SARS-CoV-2 clinical samples. 
9. The specific viral results obtained by Kraken classification should also be addressed in the Discussion/Limitations section.

Is the rationale for developing the new method (or application) clearly explained? Yes

Is the description of the method technically sound?

Yes

Are sufficient details provided to allow replication of the method development and its use by others?

Partly

If any results are presented, are all the source data underlying the results available to ensure full reproducibility?

Yes

Are the conclusions about the method and its performance adequately supported by the findings presented in the article?

Yes

Competing Interests: No competing interests were disclosed.

Reviewer Expertise: Molecular biology, viral metagenomics and bioinformatics.

I confirm that I have read this submission and believe that I have an appropriate level of expertise to confirm that it is of an acceptable scientific standard, however I have significant reservations, as outlined above.

Reviewer Report 10 August 2022

https://doi.org/10.21956/wellcomeopenres.18969.r51813

(C) 2022 Cunningham-Oakes E. This is an open access peer review report distributed under the terms of the Creative Commons Attribution License, which permits unrestricted use, distribution, and reproduction in any medium, provided the original work is properly cited.

\section{Edward Cunningham-Oakes}

University of Liverpool, Liverpool, UK

The study presented by Claro et al.

Introduction

1. Minor point, but not essential: I would encourage a quick review of punctuation/grammar for some of the longer sentences in the introduction. Alternatively, I would break up some 
of these longer sentences to help the reader.

2. The abbreviation CHIKV is not introduced elsewhere as Chikungunya virus before abbreviation.

3. As per previous point, LASV is not introduced as Lassa mammarenavirus before use of the abbreviation.

4. Missing word (highlighted in bold): 'SMART-9N recovered a high proportion of viral reads from a ZIKV isolate.'

5. In the sentence "enabling enhanced pathogen detection for both diagnostic and surveillance application of RNA viruses", amend "diagnostic" to "diagnosis", and remove the word "application".

6. Depending on how this is published, it might be worth introducing "SMART" as (Switching Mechanism at the $5^{\prime}$ end of RNA Template), as you have done in the abstract.

\section{$\underline{\text { Methods }}$}

Sample collection

1. "The supernatant was removed, and MEM supplemented with $2 \%$ fetal bovine serum, $1 \%$ penicillin, and streptomycin were added" - it is not necessary to add "were added" to the end of this sentence, as you have already stated "supplemented".

2. What percentage of streptomycin was the fetal bovine serum supplemented with?

3. I assume pencilin and streptomycin were added to prevent bacterial growth, but it may be worth stating why your MEM was supplemented with them.

4. Please describe the term "FFU" in full, before providing the acronym.

5. Stylistic suggestion "This sample was used to assess the performance of all three methods: multiplex PCR, SMART-9N, and Rapid SMART-9N, and the metagenomics approaches, SMART-9N, and Rapid SMART-9N, was tested in different serial ten-fold MEM dilutions up to". I would split this sentence into two, after the first mention of "Rapid SMART-9N", correct "metagenomics approaches" to "metagenomic approaches", and correct "was tested" to "were tested".

6. "with a cut-off value of Ct-values $\leq 37$ " -> "with a ct-value cut-off of"

7. "samples with a range of Ct-values" - can Ct-value ranges be stated in text? I know that a supplementary table is provided, but having a range in text would help readers with following the narrative without switching between supplementaries and the main text.

\section{Multiplex $P C R$}

1. Under the section "Multiplex tiling PCR", can the authors clarify what is meant by "specific bands"? Is there an amplicon size you are expecting on the gel for PCR products? 


\section{Bioinformatics workflow}

1. The workflow presented is a robust and methodologically sound approach. However, as raised by the authors, the advantage of metagenomic sequencing is the genomic characterization of known and novel viruses in an untargeted manner, whilst this workflow uses mapping to a known reference genome, based on knowledge of what is in the clinical samples (e.g. SARS-CoV-2 nasopharangeal swabs). It would probably be of wider interest (in the discussion?) as how you would see SMART sequencing being used if you were presented with a sample with no known clinical diagnostic. I assume this would be an extension of your method to detect other RNA viruses in these samples?

2. I also noted that you used results from Kraken2 to identify a co-infection in a YFV sample, and then you obtain a reference genome to assess coverage. This is not mentioned in your methods, though it is described in the results (I also assume this would be your approach for samples with no known pathogen based on clinical diagnostics?)

3. Minor typo "samtools stats and samtools depth were used to calculate longest reads and genome coverage at $20 x$ respectively." - a capital is needed at the start of this sentence.

\section{$\underline{\text { Results }}$}

1. "This approach allows for amplification of RNA in the picogram input range (data not shown)" - are there plans to include this data as a supplementary? It would be exciting to see, and also extremely relevant to clinical samples, which can be of varying concentration and quality.

2. Figure 1 - no amendments to make, but I wanted to comment that this was a very helpful visual.

\section{Multiplex PCR sequencing of ZIKV isolate and YFV and SARS-CoV-2 clinical samples}

4. Figure 2 - the figure legend (and manuscript text) refers to $\mathrm{FFU} / \mathrm{ml}$, but the $\mathrm{x}$-axis in panel $\mathrm{B}$ shows PFU/ml

5. I note that detection limits are only assessed for SMART-9N and Rapid SMART-9N methods. Do we already known the limits of detection for multiplex PCR?

6. "The sequenced YFV samples $(n=21)$ had a median Ct-values $=25.57$, between 5 and 37 generated in one 24 barcoded library." - can the authors check this sentence, as I could not quite follow it?

7. Minor/optional point: I would keep the format ranges for genome copies consistent. In the section describing YFV, you go from low to high, (1.00e00 to 1.50e10), but here, you go from high to low (2.40e05 to 1.30e02). I would go from low to high.

8. Minor typo: with an average depth of between $821.77 x$ to $1570 x$

SMART-9N and Rapid SMART-9N of ZIKV isolated-culture samples and limit of detection

1. "and submitted to SMART-9N" - subjected to? 
2. "The coverage depth was up to $10010 x$, and $154.25 x$ with $6 \mathrm{e} 00 \mathrm{FFU} / \mathrm{mL}$ of material, compatible with single-cell assays." - do you mean ranged between? Up to implies one of these numbers is the upper limit, but you wouldn't usually report the other if you are describing the upper limit in this way.

3. "The median N50 was $1.7 \mathrm{~kb}$ and when the readings" - should this be "reads?"

4. Should "ZIKV genome covers" be "ZIKV genome coverage?"

5. "and the N50 $2.27 \mathrm{~kb} "$-> "and the N50 was $2.27 \mathrm{~kb} "$

6. "with $6 \mathrm{e} 07$ of material input" - please state units. Was this FFU/mL?

\section{SMART-9N and Rapid SMART-9N of YFV clinical samples}

8. "The average coverage depth revealed higher genome depth and better coverage pattern across the genome for the metagenomics methods when compared to the multiplex PCR method." - presumably, the multiplex PCR method was specific to YFV. Do the authors know have any thoughts as to why performance is worse with a pathogen-specific assay?

9. Minor typos/sentence structure issue: "Comparable genome coverage 20 -fold across the Ctvalues between all methods is presented in Figure 3B" - could the authors look at this sentence again, as it is a little bit hard to interpret.

Rapid SMART-9N of SARS-CoV-2 clinical samples

1. Would the authors be able to clarify as to why SARS-CoV-2 were only subjected to Rapid SMART-9N?

2. "The median revealed was $91.59 \%$, minimum $84.49 \%$, and the Rapid SMART-9N $99.79 \%$, minimum of $99.57 \%$." I assume the first two values are for multiplex PCR, and the final two for Rapid SMART-9N, but this could be made clearer.

\section{Detection of other RNA viruses in clinical samples and Kraken classification}

4. "This allowed for the identification of a dsDNA virus genus Pa6virus, family Siphoviridae present in one YFV sample" - you mention (at the end of this section), the proportion of viral reads in other samples. Was there a reason that you chose to report on the Pa6virus in a YFV sample, as opposed to other identified viral reads in other samples? Was this the only evidence of putative co-infection? It may be worth noting your rationale for choosing this sample in-text.

\section{Discussion}

Please see my note in methods regarding bioinformatic workflow in samples with no known clinical diagnostic result.

Is the rationale for developing the new method (or application) clearly explained? 
Yes

Is the description of the method technically sound?

Yes

Are sufficient details provided to allow replication of the method development and its use by others?

Yes

If any results are presented, are all the source data underlying the results available to ensure full reproducibility?

Partly

Are the conclusions about the method and its performance adequately supported by the findings presented in the article?

Yes

Competing Interests: No competing interests were disclosed.

Reviewer Expertise: Metagenomics, microbial genomics, bioinformatics, pathogen detection

I confirm that I have read this submission and believe that I have an appropriate level of expertise to confirm that it is of an acceptable scientific standard, however I have significant reservations, as outlined above. 